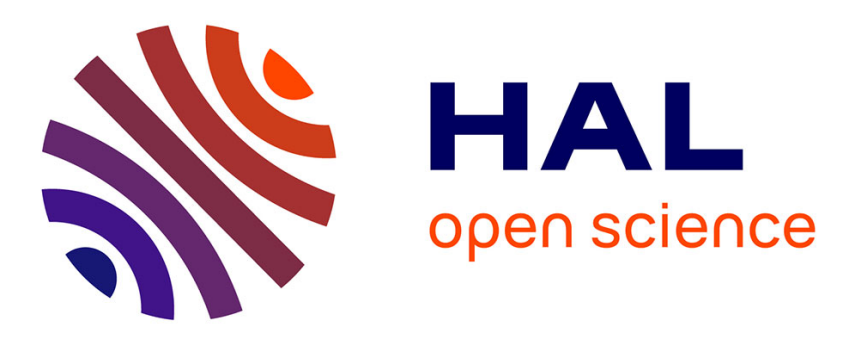

\title{
RGD nanodomains grafting onto titanium surface.
}

Guillaume Forget, Laurent Latxague, Valérie Héroguez, Christine Labrugère, Marie-Christine Durrieu

\section{To cite this version:}

Guillaume Forget, Laurent Latxague, Valérie Héroguez, Christine Labrugère, Marie-Christine Durrieu. RGD nanodomains grafting onto titanium surface.. Conference proceedings: .. Annual International Conference of the IEEE Engineering in Medicine and Biology Society. IEEE Engineering in Medicine and Biology Society. Annual Conference, 2007, pp.5107-5110. inserm-00189882

\section{HAL Id: inserm-00189882 https://www.hal.inserm.fr/inserm-00189882}

Submitted on 22 Nov 2007

HAL is a multi-disciplinary open access archive for the deposit and dissemination of scientific research documents, whether they are published or not. The documents may come from teaching and research institutions in France or abroad, or from public or private research centers.
L'archive ouverte pluridisciplinaire HAL, est destinée au dépôt et à la diffusion de documents scientifiques de niveau recherche, publiés ou non, émanant des établissements d'enseignement et de recherche français ou étrangers, des laboratoires publics ou privés. 


\title{
RGD nanodomains grafting onto titanium surface
}

\author{
G. Forget, L. Latxague, V. Héroguez, C. Labrugère, M. C. Durrieu
}

\begin{abstract}
Titanium alloys exhibit excellent biocompatibility and corrosion resistance in the body fluid and possess favorable mechanical properties. In order to study the tissue-implant interaction and to favor osteoblast-adhesion onto titanium, our work deals with the grafting of cell-binding peptides containing the Arginine-Glycine-Aspartic acid (RGD) sequence.

In the present study, we focus on the elaboration of patterned biomaterial surfaces with highly functionalized nanodomains. The strategy of RGD peptide immobilization involves first the grafting if an amino-functional organosilane (APTES). Then, each of the free amino moieties were used as an initiator core for a dendrimer-like synthesis to multiply the number of free groups available for RGD immobilization on the material surface.
\end{abstract}

\section{INTRODUCTION}

DEAL bone substitute should present a surface conductive 1 to or inducing osseointegration, regardless of implantation site, bone quality, bone quantity, etc. A common feature in engineering cell and tissue behaviors at biomaterials surfaces is thus to modify the material in order to interact selectively with a specific cell type through biomolecular recognition events.

A promising approach is to use biomimetic modification of the biomaterial with a peptide sequence containing adhesion domains of the extracellular matrix (ECM) proteins. The most used is the RGD sequence (Arg, Gly, Asp) which is known to mediate cell attachment [1].

The process of integrin mediated cell adhesion comprises a cascade of four different party overlapping events : cell attachment, cell spreading, organization of actin cytoskeleton, and formation of focal adhesions [1]. The number of attached cells is clearly related to RGD surface density [2]. Moreover, clustering the RGD sequences was shown to increase the cell motility and adhesion [3].

In the present work, we focus on the elaboration of patterned biomaterial surfaces with highly functionalized nanodomains. In this way, 3-amino-propyl-triethoxy-silane (APTES) was covalently linked to a clean titanium alloy surface which is then presenting amino moieties [4]. Next, from each amino moieties, two successives steps inspired of poly-amido-amine (PAMAM) synthesis [5] are conducted to multiply by 2 the number of amino moieties for each silanized sites. The first step is an alkylation of the amino moieties by the methylacrylate in methanol and the second is

Manuscript received April 2, 2007.

G. Forget, L. Latxague and M. C. Durrieu are with the INSERM U577 laboratory, University of Bordeaux 1, Bordeaux, France (corresponding author to contact: Guillaume Forget: phone: +33-557571730; fax: +33556900517; e-mail: guillaume.forget@bordeaux.inserm.fr).

V. Héroguez is with the LCPO, ENSCPB, Bordeaux, France; And C. Labrugère is with the ICMCB, University of Bordeaux 1, France. a Mickael addition of 1,3-propanediamine on the ester moieties of the materials. Those reactions are presented in figure 1 . The materials obtained after the alkylation with methylacrylate were named half generation as those obtained after the Mickael addition of the 1,3-propanediamine are called full generation or generation 1 or 2 .
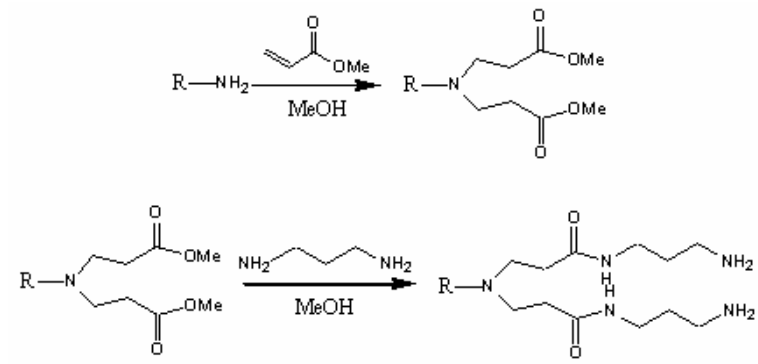

Fig. 1: Successive steps conducted for the dendron synthesis

This work proposed to synthesize and characterize all the intermediates of the generation 2 dendronized titanium; namely: silanized titanium (or generation 0), generation 0.5 (first half generation), generation 1, generation 1.5 and generation 2 , which present 4 amino moieties per fixation sites. The generation 2 dendronized titanium is represented on figure 2.

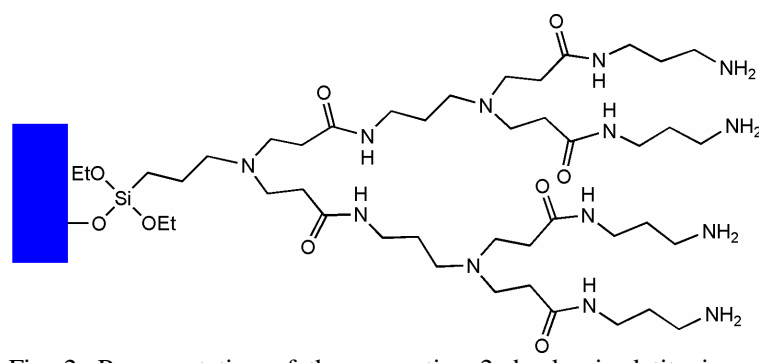

Fig. 2: Representation of the generation 2 dendronized titanium. This material present 4 amino moieties by silanized sites. The blue box stands for the titanium alloy.

The free functional sites are finally used to covalently link a RGD sequence, mediating cell attachment. The method was inspired of [4] by using 3-succimidyl-3maleimidopropianate (SMP) to activate the primary amine moieties and RGDC sequence will be grafted in a phosphate buffer.

At each step, the materials are characterized by X-Ray Photoelectron Spectroscopy (XPS) and by indirect titration with fluorescamine which is a compound reacting specifically with primary amine moieties to form a fluorescent complex.

Because the fluorescence is extinct by the proximity of the metal [6], the fluorescence can not be quantified directly on the titanium surface and the titration was carried out by measuring the fluorescamine which had not reacted and was

This material is presented to ensure timely dissemination of scholarly and technical work. 
still in the solution.

\section{MATERIALS AND METHODS}

\section{A. Materials}

3-aminopropyltriethoxysilane (APTES) was obtained from ABCR-Roth Sochiel, France. Anhydrous hexane, methanol, methylacrylate, 1,3-propanediamine, fluorescamine, anhydrous dimethylformamide (DMF), SMP, acetone, triethylamine and n-butylamine were purchased from Aldrich, France. Disks of titanium alloy (Ti-6Al-4V or TA6V) were produced by Merck Biomaterials, Darmstadt, Germany.

\section{B. Preparation of the the silanized titanium}

Mirror polished TA6V disks have been sonicated $15 \mathrm{~min}$ in ethanol and $15 \mathrm{~min}$ in acetone and hence cleaned by 48 hours washing by methanol in soxhlet extractor.

The silanization was then carried out in a dried and air free chamber that allow us to avoid the contamination of the surface by water or carbon compounds. For this reaction, the materials were first outgassed at $150^{\circ} \mathrm{C}$ under vacuum $\left(10^{-5}\right.$ Torr) for 15 hours and the silanization is then realized by immersing the materials in a $10^{-2} \mathrm{M}$ APTES solution in anhydrous hexane, under argon atmosphere [4].

This reaction was purchased for 4 hours and the materials were rinsed with anhydrous hexane and rinsed by methanol in soxhlet extractor.

At last, they are outgassed under vaccum $\left(10^{-5}\right.$ Torr $)$ for 20 hours.

\section{Preparation of the dendronized titanium}

For the half generations ( 0.5 and 1.5$)$ synthesis, the materials are immersed in $2 \mathrm{~mL}$ of a solution of $5 \mathrm{~mL}$ of methylacrylate in $5 \mathrm{~mL}$ of anhydrous methanol. This reaction is conducted for 20 hours and the materials are then rinsed with anhydrous methanol for 1 day. At last, they are sonicated for $15 \mathrm{~min}$ in anhydrous methanol and dry under vacuum ( $\mathrm{P}=10^{-4}$ Torr) for 4 hours.

The generation 1 and 2 are synthesized from the corresponding half generations by immersing them in $2 \mathrm{~mL}$ of a solution of $5 \mathrm{~mL}$ of 1,3-propanediamine in $5 \mathrm{~mL}$ of anhydrous methanol. This reaction is purchased for 48 hours and then the materials are rinsed in anhydrous methanol for 1 day, sonicated for $15 \mathrm{~min}$ in anhydrous methanol and cleaned in a methanol soxhlet extractor for 48 hours. At last, they are dried under vacuum $\left(\mathrm{P}=10^{-4}\right.$ Torr $)$ for 4 hours.

\section{Functionalization with the RGDC sequence}

Materials are then coupled with a heterobifunctional cross-linker (SMP) $\left(2.10^{-3} \mathrm{M}\right)$ in anhydrous DMF for 2 hours. Next, the materials are rinsed in anhydrous DMF for 15 hours and dried under vacuum $\left(\mathrm{T}=70^{\circ} \mathrm{C}, \mathrm{P}=10^{-4}\right.$ Torr $)$ for 4 hours

The activated materials are then immersed in $2 \mathrm{~mL}$ of a $10^{-3} \mathrm{M}$ RGDC solution in a $\mathrm{pH} 7$ phosphate buffer for 4 hours. Materials are rinsed for 2 hours with deionized water and the adsorbed water is removed under vacuum $\left(\mathrm{P}=10^{-5}\right.$ Torr) for the night (15 hours).

\section{E. XPS characterization}

XPS spectra have been recorded with a VG 220i-XL Escalab spectrometer on titanium at each step of the synthesis. Power of the monochromatized AlKa source was $100 \mathrm{~W}$ with an investigated area of about $250 \mu \mathrm{m}$. A flood gun was used for charge compensation. Acquisition of high resolution spectra was done at constant pass energy of $10 \mathrm{eV}$. Fitting was then realized with a software provided by VG Scientific, each spectrum being referenced to carbon pollution at $284.8 \mathrm{eV}$. Binding energy values are given at $\pm 0.1 \mathrm{eV}$.

\section{F. Fluorimetric characterization}

$10 \mathrm{~mL}$ of a $10^{-2} \mathrm{M}$ solution of fluorescamine in acetone is prepared. $50 \mu \mathrm{L}$ of triethylamine is added in this solution $(0.5 \%)$. Each materials are immersed in $2 \mathrm{~mL}$ of this solution for 15 hours. The titration of the unreacted fluorescamine is done by mixing $1 \mathrm{~mL}$ of the solution put on the materials with $1 \mathrm{~mL}$ of a $0.1 \mathrm{M}$ solution of $\mathrm{n}$-bytulamine in $\mathrm{pH} 9$ buffered solution.

The excitation wavelength was fixed at $390 \mathrm{~nm}$ and the emission wavelength was fixed at $460 \mathrm{~nm}$.

\section{DISCUSSION}

\section{A. XPS results.}

Silanization is an important step as regards reproducibility of chemical functionalization. Although such reaction has been extensively studied, the resulting structure, coverage, orientation, and organization of the intermediates to the generation 2 have not been studied.

Our aim is the process development of experimental dendronized titanium whose experimental atoms quantification is not too far from the theoretical ones.

Many materials were prepared to get a good $\mathrm{Si} / \mathrm{N}$ ratio without a too low $\mathrm{Ti}, \mathrm{Al}$ or $\mathrm{Si}$ signal, meaning that the molecules formed a film on the materials surface which masks the titanium. Some of the experiments done are summarized in table I. The G1-50 was prepared by using $50 \%$ in volume of 1,3-propanediamine, for G1-10 the

TABLE I

XPS QUANTIFICATIONS OF MATERIALS GENERATION 1 PREPARED DIFFERENTLY

\begin{tabular}{|c|cccccc|}
\hline \hline Materials & $\mathrm{C}$ & $\mathrm{O}$ & $\mathrm{Si}$ & $\mathrm{N}$ & $\mathrm{Ti}$ & $\mathrm{Al}$ \\
\hline $\mathrm{G} 1-50$ & 35,5 & 39,6 & 1,2 & 4,3 & 12,4 & 3,4 \\
\hline G1-10 & 32,7 & 44 & 6,3 & 1,5 & 11,8 & 2,5 \\
\hline G1-100 & 31,6 & 46,2 & 0,4 & 2,6 & 13,9 & 3,4 \\
\hline \hline
\end{tabular}

Atomic composition of generation 1 prepared with different concentrations of 1,3-propanediamine. The values are given in percentage. 
solution was $10 \%$ in volume of 1,3-propanediamine and, for G-100, the 1,3-propanediamine was used without methanol. This table show some effects which were observed on materials badly prepared.

The better concentration to use seems to be solution containing $50 \%$ of methylacrylate and $50 \%$ of methanol for the synthesis of the half generation, and $50 \%$ of 1,3-propanediamine in $50 \%$ methanol for the synthesis of the full generation. The signal for $\mathrm{Si}, \mathrm{Ti}$ and $\mathrm{Al}$ is not too low and the $\mathrm{Si} / \mathrm{N}$ ratio is very near to the theoretical value (that is to say, 5 for the generation 1 ).

The table II show the XPS quantification for the different intermediates to generation 1 dendronized titanium. The table III show the theoretical quantities of each element for one dendron on each intermediates.

TABLE II

XPS QUANTIFICATIONS OF THE INTERMIEDIATES TO THE GENERATION 1

\begin{tabular}{|c|cccccc|}
\hline \hline Materials & $\mathrm{C}$ & $\mathrm{O}$ & $\mathrm{Si}$ & $\mathrm{N}$ & $\mathrm{Ti}$ & $\mathrm{Al}$ \\
\hline 0 (silanized Ti) & 25,6 & 52,1 & 0,7 & 1,3 & 17,2 & 3,1 \\
\hline Generation 0.5 & 33,6 & 38,6 & 1,4 & 1,8 & 13,5 & 4 \\
\hline Generation 1 & 35,5 & 39,6 & 1,2 & 4,3 & 12,4 & 3,4 \\
\hline \hline
\end{tabular}

TABLE III

NUMBER OF EACH ELEMENTS FOR ALL THE INTERMEDIATES

\begin{tabular}{|c|cccc|}
\hline \hline Materials & $\mathrm{C}$ & $\mathrm{O}$ & $\mathrm{Si}$ & $\mathrm{N}$ \\
\hline 0 (silanized Ti) & 7 & 3 & 1 & 1 \\
\hline Generation 0.5 & 15 & 7 & 1 & 1 \\
\hline Generation 1 & 19 & 5 & 1 & 5 \\
\hline \hline
\end{tabular}

Those results show that the ratio $\mathrm{Si} / \mathrm{N}$ is well obtained for the different materials. The heavy carbon and oxygen pollution make difficulties to interpret those data, but the results have an evolution similar to the theory.

At last, Ti, Al and $\mathrm{V}$ percentage are decreasing, letting us think that molecular layer become more and more important, in adequation with the dendritic tree growing.

An other interesting results is the evolution of the $\mathrm{C} 1 \mathrm{~s}$ and N1s peaks of the XPS spectra presented in figure 3.

For the $\mathrm{C} 1 \mathrm{~s}$ peaks, as the generation increased, the $\mathrm{C}-\mathrm{O}$ bound become more and more important. Besides, the $\mathrm{C}=\mathrm{O}$ bound appears from the 0.5 generation and become very important in the 1.5 generation.

The N1S peaks is very thin for the silanized titanium (or generation 0), proving that the amino moieties are not protonated and in the primary amines form. As, for the generation 0.5 or for the generation 1 , the peaks became larger, proving the presence of an other amine type, linked to the tertiary amines of those two compounds.
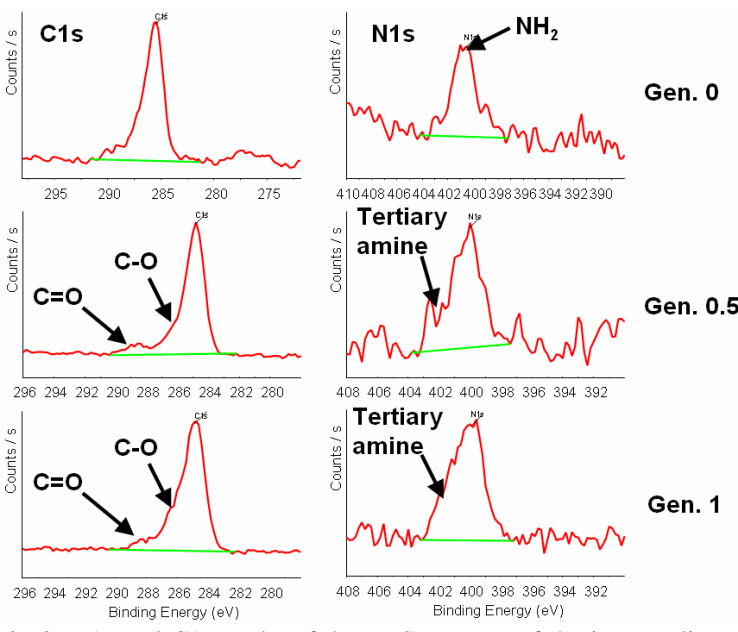

Fig 3: N1s and C1s peaks of the XPS spectra of the intermediates of the generation 2 dendronized titanium.

\section{B. Fluorimetric results}

A preliminary results give a 3.7 ratio between the silanized titanium and the generation 2 dendronized titanium, as the theoretical value was 4 .

This results let us think that this method could be useful for quantifying our primary amine density on the materials surface.

\section{PERSPeCTIVES}

The grafting of the RGD sequence is now study. It will be followed by an XPS characterization and a fluorimetric titration with benzoin which react specifically with the guanido moieties of the RGD sequence [7].

The generation 2 preparation is now carried out and will be characterized soon.

\section{OTHER WAY POSSIBLE}

An other way for nanodomaines synthesis is also studied. It consists of the use of nanoparticles of a copolymer of polynorbornene-polyethyleneoxide [8] functionalized with either a carboxyl group, either a RGD sequence.

Those nanoparticles can be grafted on a silanized titanium surface with the carboxyl group and could be considered as nanodomains itself.

The diameter of the nanoparticles is between $200 \mathrm{~nm}$ and $500 \mathrm{~nm}$, it can be define very precisely as the concentration of RGD sequence on its surface.

\section{CONCLUSION}

Materials surface can be chemically modified in order to present RGD peptides nanodomains. Various density of nanodomaines as various densities of RGD peptides by nanodomaines can be carried out and will be useful for studying the influence of clustering the RGD sequence on osteoblasts adhesion. 


\section{REFERENCES}

[1] U.Hersel, , C. Dahmen and H. Kessler, " RGD modified polymers: biomaterials for stimulated cell adhesion and beyond", Biomaterials, 24, Nov. 2003, pp. 4385-4415

[2] S. P. Massia and J. A. Hubbell, “An RGD Spacing of $440 \mathrm{~nm}$ Is Sufficient for Integrin $\alpha_{v} \beta_{3}$-Mediated Fibroblast Spreading and 140 $\mathrm{nm}$ for Focal Contact and Stress Fiber Formation", The Journal of Cell Biology, 114, Sep. 1991, pp 1089-1100

[3] G. Maheshwari, G. Brown, D. A. Lauffenburger, A.Wells and L. G. Griffith, "Cell adhesion and motility depend on nanoscale RGD clustering “, Journal of Cell Science, 113, May 2000, pp 1677-1686

[4] M. C. Porte-Durrieu, F. Guillemot, S. Pallu, C. Labrugere, B. Brouillaud, R. Bareille, J. Amedee, N. Barthe, M. Dard and C. Baquey, "Cyclo-(DfKRG) peptide grafting onto Ti-6Al-4V: physical characterization and interest towards human osteoprogenitor cells adhesion", Journal of Materials science, 15, Aug. 2004, pp 779-786

[5] D. A. Tomalia , H. Baker, J. Dewald, M. Hall, G. Kallos, S. Martin, J. Roeck, J. Ryder, P. Smith, "A New Class of Polymers: StarburstDendritic Macromolecules”, Polymer Journal, 17 n²1, 1985 , pp 117 132

[6] P. M. Whitmore, H. J. Robota and C. B. Harris, "Mechanisms for electronic energy transfer between molecules and metal surfaces: A comparison of silver and nickel." The Journal of Chemical Physics, Aug. 1982, Vol 77 n³, pp 1560-1568

[7] Y. Ohkura and M. Kai, "Fluorimetric determination of monosubstitued guanido compounds with benzoindimethylformamide reagent", Analytica Chimica Acta, 106, 1979, pp 89-94

[8] D. Quémener, A. Chemtob, V. Héroguez and Y. Gnanou, "Synthesis of latex particles by ring-opening metathesis polymerization", Polymer, Vol .46 n4, Feb 2005, pp 1067-1075 